sciousness, but she remained unresponsive to commands. During this time she was oliguric with a urinary output of $363 \mathrm{ml} / 24$ hours.

Labour occurred spontaneously 18 hours after admission and rapidly progressed to a normal delivery of a stillborn baby boy weighing $2500 \mathrm{~g}$. After delivery the patient's degree of consciousness improved rapidly, and within an hour she was able to answer questions appropriately. Within the next 24 hours her cardiovascular state improved and the dobutamine infusion was withdrawn as urinary output returned to normal.

Computed tomography of the liver was repeated twice: eight days after admission the attenuation value had risen to 48 Hounsfield units and by 21 days it had returned to normal at 55 Hounsfield units. A liver biopsy was carried out on the twelfth day after admission and showed preservation of the normal architecture with prominent cholestasis, small areas of liver cell necrosis, mild inflammatory infiltrate in the portal areas, and some microvesicular fatty change. These features were consistent with resolving acute fatty liver of pregnancy.

Over the next two weeks results of liver function tests continued to improve and, after an initial rapid fall in aminotransferase activities, returned to normal four weeks after admission. Fifteen months later the patient was still well.

\section{Discussion}

The differential diagnosis of a patient presenting with hepatic failure in late pregnancy includes acute fatty liver of pregnancy, acute hepatitis, and deterioration of chronic liver disease. Exact diagnosis, on which management will depend, can often be made only after a liver biopsy has been performed, a procedure that is hazardous if liver failure is associated with coagulation disorders. In our patient the diagnosis of acute fatty liver of pregnancy was initially suggested by the typical history of prodromal malaise and vomiting and the rapid onset of hepatic encephalopathy with profound hypoglycaemia and only small increases in transaminase activities. Although there was some improvement in the degree of consciousness with correction of the hypoglycaemia, the ap- preciable improvement after delivery was also typical of acute fatty liver of pregnancy. ${ }^{4}$

Computed tomography has been shown to be an accurate method of estimating the fat content of the liver. ${ }^{5}$ It can be used to assess the overall pattern of fatty change and is not prone to sampling errors with non-uniform fat distribution, which may occur in liver biopsy specimens. It is non-invasive and has the advantage of providing an immediate result and may be safely carried out in the presence of coagulation abnormalities. In our patient computed tomography established the diagnosis of acute fatty liver of pregnancy within three hours of admission, thus facilitating her further management.

Computed tomography of the liver in late pregnancy is a fairly safe technique. Studies in our radiology department using an Alderson Rando anthropomorphic phantom show that the incidental dose of radiation from a single $8 \mathrm{~mm}$ computed tomographic slice, $6 \mathrm{~cm}$ away, at mid-hepatic level results in a dose to the fetus that is less than that given by a single posteroanterior fetal $x$ ray examination (unpublished data).

This case confirms the value of computed tomography in the diagnosis of liver disease of late pregnancy. We consider that further studies are indicated and suggest that this technique may become the investigation of choice for acute fatty liver of pregnancy.

\section{References}

1 Sherlock S. Acute fatty liver of pregnancy and the microvesicular fat diseases. Gut 1983;24:265-9. 2 Hatfield AK, Stein JH, Greenberger NJ, Abernethy RW, Ferris TF. Idiopathic acute fatty liver of pregnancy: death from extrahepatic manifestations. American Journal of Digestive Diseases 1972;17:167-78.

3 de Swiet M. Some rare medical complications of pregnancy. BrMed $\mathcal{f}$ 1985;290:2-4.

4 Burroughs AK, Seong NH, Dojcinov DM, Scheuer PJ, Sherlock SV. Qf Med 1982;51:481-97.

5 Bydder GM, Kreel L, Chapman RWG, Harry D, Sherlock S, Bassam L. Accuracy of computed tomography in diagnosis of acute fatty liver. Br Med f 1980;281:1042.

\title{
Detection of lymphocytotoxic antibodies in relatives of patients with type I diabetes
}

\author{
J A CHARLESWORTH, P PEAKE, L V CAMPBELL, J RUMMA, B A PUSSELL, \\ N HOWARD, G J ELDER
}

\begin{abstract}
Concentrations of lymphocytotoxic antibodies were measured in serum samples from 19 patients recently diagnosed as having type I diabetes and 43 healthy relatives ( 33 consanguineous and 10 non-consanguineous). The specificity of the reaction was tested at $15^{\circ} \mathrm{C}$ and $37^{\circ} \mathrm{C}$ against $\mathrm{T}$ lymphocytes and purified
\end{abstract}

\footnotetext{
Department of Medicine, Prince Henry and Prince of Wales Hospitals, Sydney, New South Wales, Australia

J A CHARLESWORTH, MD, FRACP, renal physician

P PEAKE, PHD, scientific office

J RUMMA, PHD, senior scientific officer

B A PUSSELL, PHD, FRACP, renal physician

N HOWARD, MD, FRACP, staff endocrinologist

G J ELDER, FRACP, medical registrar

Diabetes Centre, St Vincent's Hospital, Sydney, New South Wales 2010, Australia

L V CAMPBELL, MRCP, FRACP, visiting physician

Correspondence to: Dr Charlesworth.
}

helper/inducer and cytotoxic/suppressor subsets. The concentrations of lymphocytotoxic antibodies in each of the three test groups were significantly higher than those in controls (type I patients, $p<0.005$; consanguineous relatives, $p<0.001$; and nonconsanguineous relatives, $p<0.002$ ). The frequency of detection of the antibodies was also greater in each of the study groups $(\mathbf{p}<0.01, p<0.01$, and $\mathbf{p}<0.05$, respectively). Cytotoxicity affected both subsets at $15^{\circ} \mathrm{C}$ but only cytotoxic/suppressor cells at $37^{\circ} \mathrm{C}$.

The finding of lymphocytotoxic antibodies in healthy relatives of type I diabetics, irrespective of consanguinity, suggests that an environmental agent such as a virus is at least partially responsible for this lymphocytotoxic effect. Furthermore, the residual cytotoxic/suppressor cell killing at $37^{\circ} \mathrm{C}$ could explain the defect of suppressor cells observed in these patients.

\section{Introduction}

Lymphocytotoxic antibodies occur in several immunological diseases in which viral infection is suspected to play a part in pathogenesis. ${ }^{1-3}$ Their extensive characterisation in patients with 
systemic lupus erythematosus has shown that they include both IgM and IgG classes, ${ }^{4}$ require specific temperature conditions for cytotoxicity in vitro, ${ }^{5}$ and react with both major subsets of $\mathrm{T}$ lymphocytes. ${ }^{6}$ This reactivity and the effects (both cytotoxic ${ }^{7}$ and non-cytotoxic ${ }^{8}$ ) noted at $37^{\circ} \mathrm{C}$ have implicated lymphocytotoxic antibodies in immunoregulation. Messner and De Horatius observed lymphocytotoxicity in a high proportion of serum samples from subjects in regular contact with patients with systemic lupus erythematosus, irrespective of consanguinity. ${ }^{9}$ They concluded that a transmissible agent contributed to the development of lymphocytotoxic antibodies in these subjects.

Similar questions regarding pathogenesis apply to type I diabetes, as disturbances of immunoregulation are suspected and it has been proposed that viral infection is important in mediating pancreatic injury. Indeed, lymphocytotoxic antibodies have been found in many patients recently diagnosed as having type I diabetes and also in experimental models of the disease. ${ }^{210}$ If this lymphocytotoxic activity in type I diabetes reflects viral activity (at least in some patients) then it might be expected to occur in healthy relatives in regular contact with these patients. We therefore examined the cell specificity and temperature dependence of this reaction, these being factors likely to influence its immunoregulatory potential, in 19 families each containing one member recently diagnosed as having type I diabetes. Thirty three consanguineous relatives and 10 nonconsanguineous household contacts were also available for investigation.

\section{Subjects and methods}

Patients and relatives-Nineteen patients with type I diabetes (mean age 15 years; range 2-40) were studied over 12 months. Blood samples were taken during their initial admission to hospital to stabilise their disease; no other selection criteria were used. All had been diagnosed during the two weeks before admission. At the time of sampling satisfactory control of blood glucose concentration $(<12 \mathrm{mmol} / 1(216 \mathrm{mg} / 100 \mathrm{ml}))$ had been achieved in all patients, and none were ketotic. Thirty three consanguineous relatives (21 parents and 12 first degree siblings) and 10 non-consanguineous relatives of the patients were also studied. One relative was available in seven cases, two relatives in five cases, three relatives in three cases, four relatives in three cases, and five relatives in one case. All relatives, except one parent, were in regular household contact with the patients. These subjects were well, and none had a history of immunological disease or recent infection.

Control subjects - These comprised 34 healthy medical and laboratory staff and 20 parents (matched for age and sex with the parents of the diabetic patients) of children undergoing major urological surgery. This second group was studied because of the possible immunological effects of stress on the relatives of ill patients. The first control group (staff) was tested intermittently throughout the study to assure no appreciable change in the distribution of positivity for lymphocytotoxic antibodies. Samples from the second group (parents) were taken regularly throughout the 12 months of the study.

Purification of $T$ cell subsets-High concentrations of helper/inducer (OKT4 positive, Ortho Labs) and cytotoxic/suppressor (OKT8 positive) cells were prepared by the following method: $(a)$ Ficoll-Hypaque centrifugation of fresh heparinised blood and subsequent fractionation with nylon wool (to obtain purified T cells); $(b)$ these $\mathrm{T}$ cells were incubated with monoclonal antibody to either the OKT4 or OKT8 positive subset for 30 minutes at $20^{\circ} \mathrm{C} ;(c)$ the mixture was further incubated at $37^{\circ} \mathrm{C}$ for 90 minutes in the presence of rabbit serum as a source of complement (to cause lysis of unwanted cells); and $(d)$ lysed cells were removed by further Ficoll-Hypaque centrifugation. Cell purity was around $90 \%$ for each subset, as confirmed by immunoperoxidase staining with the respective monoclonal antibody.

Measurement of lymphocytotoxic antibodies-This assay was based on that of Terasaki and McClelland, as modified by Quin et al. ${ }^{112}$ Serum samples were stored in liquid nitrogen (and not thawed) before assay. Each sample was tested against three target cells-namely, T cells purified with nylon wool, OKT 4 positive cells, and OKT 8 positive cells. The assay was performed by incubating target cells $\left(2 \times 10^{6}\right.$ cells $\left./ \mathrm{ml}\right)$ with undiluted test serum and subsequently adding rabbit serum as a source of complement to achieve cell lysis. The final mixture was incubated for three hours at $15^{\circ} \mathrm{C}$ (or $37^{\circ} \mathrm{C}$ ) and killing of cells assessed by trypan blue exclusion. All samples were assayed at $15^{\circ} \mathrm{C}$, and 14 of these (once found to be positive) further examined at $37^{\circ} \mathrm{C}$. Five normal serum samples were tested simultaneously in each assay performed at $37^{\circ} \mathrm{C}$ because of greater intra-assay variation at this higher temperature.

Statistics-Overall differences in data for the four groups were tested by a
Kruskal-Wallis one way analysis of variance and $\chi^{2}(2 \times 4)$ analysis. The differences in concentrations of lymphocytotoxic antibodies between serum samples from controls and those from each of the three study groups were assessed by the Wilcoxon test for unpaired samples. Differences in frequency of samples positive for lymphocytotoxic antibodies were assessed by the $\chi^{2}$ test with Yates's correction and a two tailed Fisher exact test.

\section{Results}

Frequency and specificity of lymphocytotoxic antibodies-Figures 1 and 2 show the data for the four groups. Preliminary analysis showed overall differences in both the concentrations of antibodies $(p<0.005$; KruskalWallis test) and the frequency of samples positive for antibodies (that is, lymphocytotoxic antibodies $>18 \%$ killing, $\mathrm{p}<0.005 ; \chi^{2}$ analysis). Specific

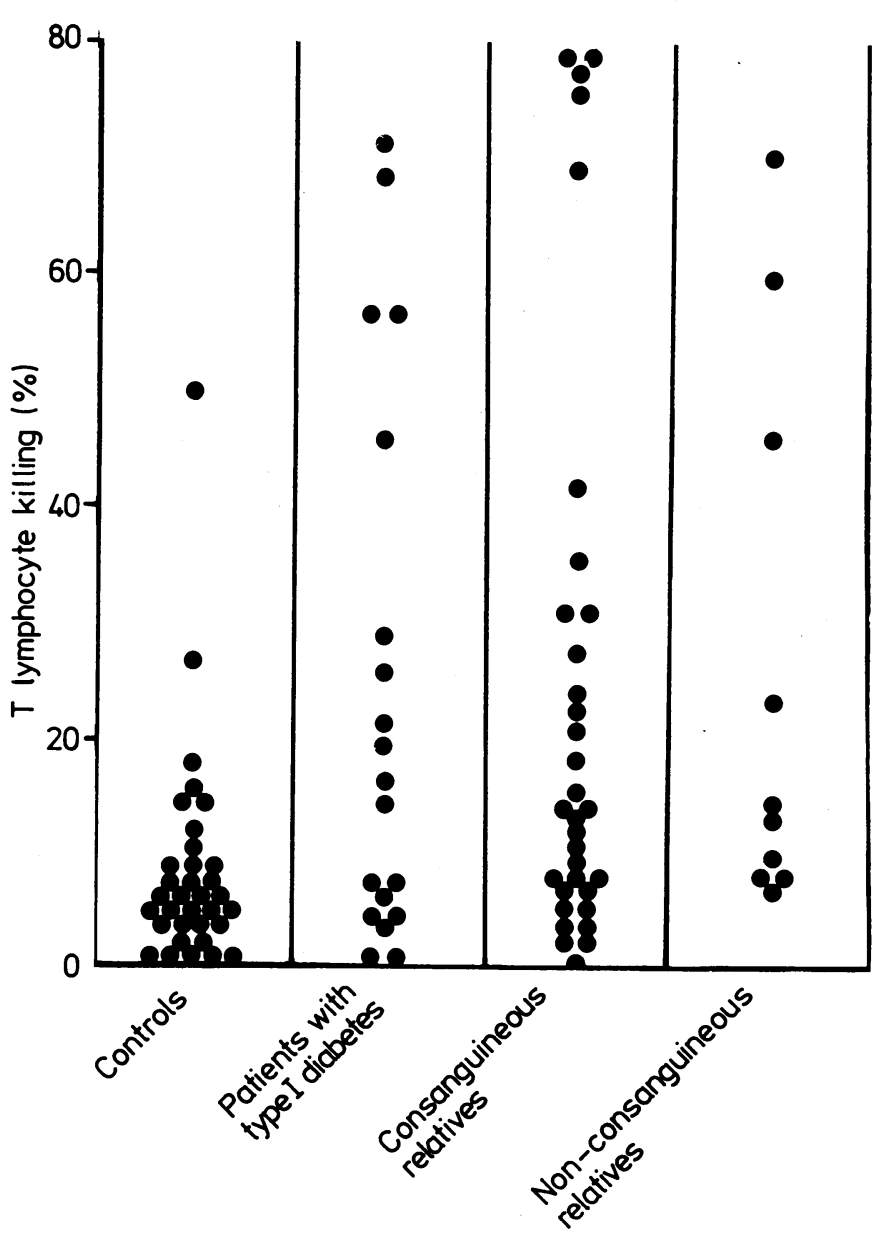

FIG 1-Concentrations of lymphocytotoxic antibodies in normal controls, patients with type I diabetes, and consanguineous and non-consanguineous relatives.

analysis of individual groups showed that the concentration of antibodies was significantly higher in each group than in controls: type I diabetic patients, $\mathrm{p}<0.005 ;$ consanguineous relatives, $\mathrm{p}<0.001$; and nonconsanguineous household contacts, $\mathrm{p}<0.002$ (Wilcoxon's test). The frequency of samples positive for lymphocytotoxic antibodies was also greater in each of the test groups: type I diabetics ( $9 / 19$ positive), $\mathrm{p}<0.01$; consanguineous relatives ( $14 / 33$ positive), $\mathrm{p}<0.01$; and nonconsanguineous relatives ( $4 / 10$ positive), $p<0.05$ ( $\chi^{2}$ analysis with Yates's correction). These $p$ values were confirmed by Fisher's exact test $(p<0.01$, $\mathrm{p}<0.01$, and $\mathrm{p}=0.035$, respectively).

At least one healthy member of 12 out of the 19 families was positive for lymphocytotoxic antibodies. In four families two members were positive, and in one family three members were positive. Only one of the 20 parents of children undergoing major surgery had antibodies $>10 \%$. The levels of killing of lymphocytes in each of the groups of diabetics and their relatives were significantly higher than values in this group of parents $(p<0.001$ for each group) 
Serum samples from both diabetic patients and their relatives showed predominant killing of $\mathrm{OKT} 4$ positive cells when tested at $15^{\circ} \mathrm{C}$. In contrast, there was significant residual $\mathrm{OKT} 8$ cell killing at $37^{\circ} \mathrm{C}$, while OKT4 cytotoxicity was negligible when tested at this higher temperature (fig 2).

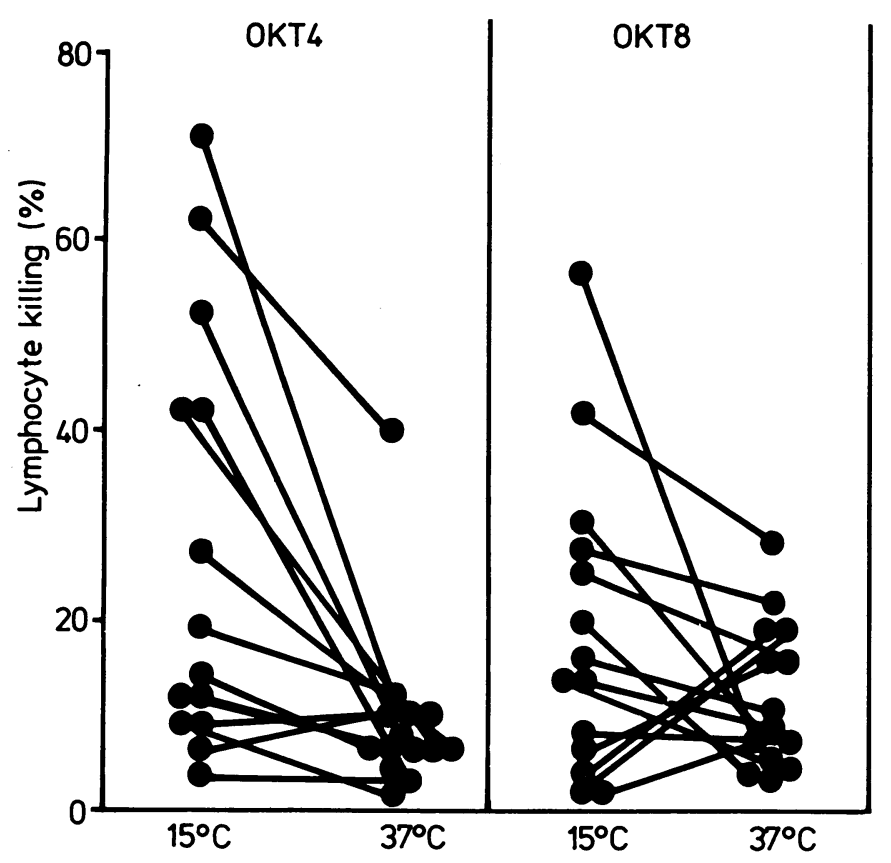

FIG 2-Comparison of serum concentrations of lymphocytotoxic antibodies at $15^{\circ} \mathrm{C}$ and $37^{\circ} \mathrm{C}$ against highly concentrated OKT4 and OKT8 positive cells. Values at $37^{\circ} \mathrm{C}$ were derived by subtracting the highest concentration of lymphocytotoxic antibodies in five normal serum samples from that observed in test samples.

\section{Discussion}

This study shows the high incidence of serum lymphocytotoxicity in both patients with type I diabetes and their healthy relatives. Although the mean age of the control and test populations differed, there is no evidence to suggest that the concentration of lymphocytotoxic antibodies varies noticeably within the overall age range used in this study (it increases somewhat after the age of 60). The frequency of antibodies in the patients with type I diabetes was slightly higher than that observed by Serjeantson $e t a l,{ }^{2}$ and this is probably explained by our restriction of sampling to within 14 days of clinical diagnosis.

Three pieces of data suggest that an environmental agent-such as a virus-was responsible, at least in part, for this serum lymphocytotoxicity. Firstly, several studies have shown the reliability of serum lymphocytotoxic antibodies as a non-specific marker of recent viral infections. ${ }^{13}$ Secondly, the concentration of the antibodies declines progressively in most patients within the first year after diagnosis. ${ }^{2}$ This pattern contrasts with that observed in patients with autoimmune diseases, such as systemic lupus erythematosus, in which serum lymphocytotoxicity persists for many years. ${ }^{14}$ Finally, the detection of the antibodies in nonconsanguineous contacts suggests that non-genetic factors influence the frequency of this reaction. While it is recognised that environmental stress may also alter immunological function, we did not find a significant rise in concentration of the antibodies in the parents of children undergoing major surgery. Furthermore, we have not observed appreciable lymphocytotoxicity in subjects with nonspecific upper respiratory viral infection (unpublished findings).

The effect of lymphocytotoxic antibodies on immunoregulatory function in vivo remains contentious. Though maximum killing (predominantly against the OKT4 subset) was observed at $15^{\circ} \mathrm{C}$ in vitro, we found significant residual cytotoxicity against the OKT8 subset when serum samples were retested at $37^{\circ} \mathrm{C}(\mathrm{OKT} 4$ cell killing had fallen to negligible levels at this higher temperature). This finding could explain the defect in function of suppressor cells (contained within the group of cells staining for the OKT8 phenotype) that has been described in patients with type I diabetes. ${ }^{15} 16$ Our data do not necessarily, however, implicate lymphocytotoxic antibodies in the pathogenesis of pancreatic injury. Indeed, we did not define the duration of the reaction before the onset of clinical diabetes. If lymphocytotoxic antibodies are found to have a role in mediating damage of islet cells then purified antibodies might provide a suitable probe for examining antigens on the surface of lymphocytes, which are relevant to the mediation of this damage.

We thank Drs G Antony and W Kidson for allowing us to study their patients.

\section{References}

1 Mittal KK, Rossen RD, Sharp JT, Lidsky MD, Butler WT. Lymphocyte cytotoxic antibodies in systemic lupus erythematosus. Nature 1970;225:1255-6.

2 Serjeantson S, Theophilus J, Zimmet P, Court J, Crossley JR, Elliott RB. Lymphocytotoxic antibodies and histocompatibility antigens in juvenile-onset diabetes mellitus. Diabetes antibodies and

3 van den Noort S, Stjernholm RL. Lymphotoxic activity in multiple sclerosis serum. Neurology (NY) 1972;21:783-93.

4 Okudaira K, Tanimoto K, Aikawa T, Horiuchi Y, Aotsuka S. Heterogeneity of antilymphocyte antibody in SLE and its correlation with disease activity. Scand $\mathcal{J}$ Rheumatol 1983;12:21-8.

5 Sakane T, Steinberg AD, Reeves JP, Green I. Studies of immune functions of patients with systemic lupus erythematosus. Complement-dependent immunoglobulin $M$ anti-thymusderived cell antibodies preferentially inactivate suppressor cells. $\mathcal{f}$ Clin Invest 1979;63:954-65.

6 Morimoto C, Reinherz EL, Distaso JA, Steinberg AD, Schlossman SF. Relationship between systemic lupus erythematosus $\mathrm{T}$ cell subsets, anti- $\mathrm{T}$ cell antibodies and $\mathrm{T}$ cell functions. $\mathcal{F} \mathrm{Clin}$ Invest 1984;73:689-700.

7 Okudaira K, Searles RP, Tanimoto K, Horiuchi Y, Williams RC. T lymphocyte interaction with immunoglobulin $\mathrm{G}$ antibody in systemic lupus erythematosus. 7 Clin Invest 1982;69:1026-38.

8 Quin JW, Charlesworth JA, Yasmeen D, Macdonald GJ, Pussell BA. Lymphocytotoxins in infectious mononucleosis: a non-cytotoxic effect on lymphocytes at $37^{\circ} \mathrm{C}$ and the influence of infectious mononucleosis: a non-cytotoxic effect on lymphocytes at $37^{\circ} \mathrm{C}$ and the in

9 De Horatius RJ, Messner RP. Lymphocytotoxic antibodies in family members of patients with systemic lupus erythematosus. $\mathcal{F}$ Clin Invest 1975;55:1254-8.

10 Dyrberg T, Poussier P, Nakhooda F, Marliss EB, Lernmark A. Islet cell surface and lymphocyte antibodies often precede the spontaneous diabetes in the BB rat. Diabetologia 1984;26:159-65.

11 Terasaki PI, McClelland JD. Microdroplet assay of human serum cytotoxins. Nature 1964;204 998-1000.

12 Quin JW, Charlesworth JA, Lee CH, Macdonald GJ. Studies of lymphocytotoxins in infectious mononucleosis: reduced lymphocyte killing in the acute phase. Clin Exp Immunol 1980;39. $588-92$.

13 De Horatius RJ. Lymphocytotoxic antibodies. Prog Clin Immunol 1980;4:151-74.

14 Winfield JB, Winchester RJ, Kunkel HG. Association of cold-reactive antilymphocyte antibodies with lymphopenia in systemic lupus erythematosus. Arthritis Rheum 1975;18:587-94.

15 Lederman MM, Ellner JJ, Rodman HM. Defective suppressor cell generation in juvenile onset diabetes. F Immunol 1981;127:2051-5.

16 Slater LM, Murray SL, Kershnar A, Mosier MA. Immunological suppressor cell activity in insulin-dependent diabetes. $\mathcal{f}$ Clin Lab Immunol 1980;3:105-9.

(Accepted 7 November 1985)

\section{YEARS AGO}

A man, styling himself "Professor" Stephen Jarrett, carrying on the business of a herbalist at Croydon, was summoned by the Commissioners of Inland Revenue for selling certain medicines without paying duty on the same. An officer of Inland Revenue purchased at the defendant's shop a bottle of "neuralgic mixture," which was described as being good for sciatica and other complaints, and other so-called never-failing remedies liable to duty. The defence was, that the defendant did not profess to practise any particular art in compounding the neuralgic mixture, which was "one simple thing diluted with water," and offered to the public as a so-called specific and it was held that no Government duty was applicable to any medicine compounded as that was, unless the vendor had at the time letters patent for the exclusive sale of that particular compound. The defence that had been raised was a very ingenious one, but it proved to be wrong in point of law. As a matter of fact, there is no such thing existing as letters patent for any medicine. All medicines held out to the public as nostrums are liable to duty. The defendant was here himself a victim of the error under which the public in general labour. The so-called system of patent medicines, and of stamps thereon, breeds a delusion that such nostrums are patents protected by law as being new inventions, and having a sort of Government approval. This delusion will only be dispelled by abolishing the whole system. (British Medical Fournal 1886;i:31.) 